\title{
INSIGNIFICANCE OF STOCK MARKET INVESTMENT AMONG COLLEGE TEACHERS WORKING IN THE JURISDICTION OF MANGALORE UNIVERSITY
}

\author{
Dr. Yathish Kumar ${ }^{* 1}$, Mr. Abhinandan 凶(iD) \\ ${ }^{* 1}$ Associate Professor, University College, Hampanakatte, Mangalore, India \\ 2 Research Scholar, Mangalore University, Mangalagangothri, India
}

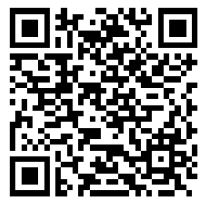

DOI: https://doi.org/10.29121/granthaalayah.v9.i2.2021.3242

Article Type: Research Article

Article Citation: Dr. Yathish Kumar, and Mr. Abhinandan. (2021).

INSIGNIFICANCE OF STOCK

MARKET INVESTMENT AMONG

COLLEGE TEACHERS WORKING IN

THE JURISDICTION OF

MANGALORE UNIVERSITY.

International Journal of Research GRANTHAALAYAH, 9(2), 38-45.

https://doi.org/10.29121/granthaa

layah.v9.i2.2021.3242

Received Date: 20 January 2021

Accepted Date: 19 February 2021

Keywords:

Investment Behaviour

Insignificance

Capital Market

\section{ABSTRACT}

The competency of a teacher is a major determinant of the quality of the education. Teacher's professional advancement is decided by many factors. One of the main factors which strongly influence the efficiency of teacher is his quality of life. The quality of one's life is closely related to the level consumption, savings and investment. Investments in stock market indicate high quality of life. But many research found that most of the teachers not investing in stock market. Much research done related to investment pattern of teaching faculty and investment behaviour of teaching faculty. These researches found out that teachers preferred to invest in banking investment avenues. But a less number of researches did to identify the reason for not investing in stock market avenues. Therefore this paper tries to identify the reasons for insignificance of stock market among teaching faculty. To this paper both primary data and secondary data were used. Primary data were collected through structured questionnaire and for secondary data referred various online journals and websites.

\section{INTRODUCTION}

"Anyone who is not investing now is missing a tremendous opportunity."-

The stock market in India is more efficient than banking system on account of the enabling government policies and that stock market development has a key role to play in the reforms of system by generating competition for funds mobilization and allocation. Hence, an efficient capital market would contribute to long term growth. According to RBI the flow of funds in the private corporate sector shows that there is growing reliance of the private corporate sector on external financing. The equity market in developing countries until the mid-1980s generally suffered from the classical defects of bank-dominated economies, that is, shortage of equity capital, lack of liquidity, absence of foreign institutional investors, and lack of investor's confidence in the stock market. Since 1986, the capital markets of the developing countries started developing with financial liberalization and the easing of legislative and administrative barriers and the adoption of tougher regulations to boost investor's confidence.

(C) 2021 The Author(s). This is an open access article distributed under the terms of the Creative Commons Attribution License, which permits unrestricted use, distribution, and reproduction in any medium, provided the original author and source are credited. 
In the history of International Finance, the year 1992- 1993 may be seen as a watershed year in which emerging markets came into their own as capital raising mechanisms and became firmly established as a distinct asset class for the word's investment community with financial liberalization. Recent days there is much scope to capital Market investment. Indian Equity Market is making its mark on the global scenario. It is one of the most sought after securities market around the world. Very recently the two stock exchanges, the Bombay Stock Exchange (BSE) and National Stock Exchange (NSE) scaled new heights when their benchmark indices BSE Sensex and NSE Nifty respectively touched highest record levels to date. The experts are upbeat about the indices and anticipate closing fiscal year on yet new record level in March 2018. Of course the reason for this scenario could be many, but how does it translate to retail investors. This paper tries to identify the reasons for insignificance of stock market among teaching faculty.

\section{Why Teachers}

Teaching is the one of oldest, noble profession across the globe. Teachers are an important driving force and backbone of our society. By indulging in the teaching profession, teachers are able to earn handsomely, at the same time,. Now a day's Teachers and professors of schools, colleges are enjoying convenient working hours, weekly off and also twice in year vacation. In addition to this implementation of 7 th pay, gives higher packages to them. Therefore the person those who wants to have career without sacrificing family life with higher salaries prefers this job. In this field time bound promotion in terms of monitory returns is assured to them So, attitude of teachers towards consumption, savings and investment would reflect their economic behaviour, which would not only influence quality of life, but also the profession and education system as well.

\section{OBJECTIVES OF THE STUDY}

- To know the Investment area of teaching faculty.

- To know the problems faced while making investment.

- To know the reasons for not investing in stock market.

\section{RESEARCH METHODOLOGY}

The research study is based on both primary and secondary data. Primary data has been collected by conducting a survey among 100 samples of teachers of Mangalore University. The secondary data have been collected from books, journal, newspaper, periodicals, reports, internet and published and unpublished thesis.

\section{ANALYSIS AND INTERPRETATION}

Simple percentage analysis was used to analyses the collected data. It states the frequency and percentage of the profile, attitude and opinion regarding the people.

\subsection{DEMOGRAPHIC PROFILE OF THE RESPONDENTS}

Demographic profile of the respondents means personal background of the respondents. Following table shows the personal information of teaching faculties.

\begin{tabular}{|c|c|c|c|c|}
\hline & & No. of Respondents & Total & $\begin{array}{c}\text { Percentage } \\
\%\end{array}$ \\
\hline \multirow[t]{2}{*}{ Gender } & Male & 57 & \multirow[b]{2}{*}{100} & $57 \%$ \\
\hline & Female & 43 & & $43 \%$ \\
\hline \multirow[t]{4}{*}{ Age group } & Below 25 & 68 & \multirow{4}{*}{100} & $68 \%$ \\
\hline & Between 25-35 & 24 & & $24 \%$ \\
\hline & Between 35-50 & 4 & & $4 \%$ \\
\hline & Above 50 & 4 & & $4 \%$ \\
\hline
\end{tabular}




\begin{tabular}{|c|c|c|c|c|}
\hline \multirow[t]{4}{*}{ Education Qualification } & PG Only & 78 & \multirow{4}{*}{100} & $78 \%$ \\
\hline & PG with M.PHIL & 4 & & $4 \%$ \\
\hline & PG with NET/SLET & 12 & & $12 \%$ \\
\hline & Ph.D. & 6 & & $6 \%$ \\
\hline \multirow{4}{*}{ Experience } & Less than 1 year & 27 & \multirow{4}{*}{100} & $27 \%$ \\
\hline & 1 to 5 years & 58 & & $58 \%$ \\
\hline & 5 to 10 years & 5 & & $5 \%$ \\
\hline & 10 years and above & 9 & & $9 \%$ \\
\hline \multirow[t]{2}{*}{ Marital Status } & Married & 11 & \multirow[b]{2}{*}{100} & $11 \%$ \\
\hline & Unmarried & 89 & & $89 \%$ \\
\hline \multirow[t]{3}{*}{ Category of College } & Government College & 19 & \multirow{3}{*}{100} & $19 \%$ \\
\hline & Private College & 63 & & $63 \%$ \\
\hline & Government aided college & 17 & & $17 \%$ \\
\hline \multirow[t]{4}{*}{ Annual income } & Less than 3 Lakhs & 82 & \multirow{4}{*}{100} & $82 \%$ \\
\hline & 3 to 5 Lakhs & 14 & & $14 \%$ \\
\hline & 5 to 8 Lakhs & 2 & & $2 \%$ \\
\hline & Above 8 Lakhs & 2 & & $2 \%$ \\
\hline \multirow[t]{4}{*}{ Annual Savings } & Less than 1 Lakh & 86 & \multirow{4}{*}{100} & $86 \%$ \\
\hline & 1-2 Lakhs & 9 & & $9 \%$ \\
\hline & 2-3 Lakhs & 5 & & $5 \%$ \\
\hline & Above 3 Lakhs & 0 & & $0 \%$ \\
\hline
\end{tabular}

\section{Source: Primary Data}

From the above table it is clearly shows that in Dakshina Kannada district majority teaching faculty come under age group below 25 years (68\%) and 78\% of the respondents pursued Post graduation only. For effective teaching experience is matter from the research it is found that majority of respondents have experience between 1 to 5 years (58\%).Here it is clears that $11 \%$ of respondents are married and remaining $89 \%$ of respondents are unmarried. Researcher majority data collected from teaching faculties of who worked in Private colleges. As generally known teacher are paid less and expected from them is more. When we look at the table we find that majority of teaching faculties' annual income is less than 3 Lakhs. Obliviously when income is low savings also become low. Majority of the respondents saves less than 1Lakh (86\%) and no one saves more than 3 Lakhs.

\subsection{INVESTMENT AREA OF TEACHING FACULTY}

Investment areas means in which field investor invest their fund. Here considered major investment area Banking and share market. It is feels that banking sector has safest investment avenues and in share market has more return investment avenues. Following Table shows that preferred invest sector.

Table 2: Investment Sector of Teaching faculties

\begin{tabular}{|c|c|c|}
\hline Investment Area & No. of respondents & Percentage \\
\hline Banking Only & 71 & $71 \%$ \\
\hline Share Market Only & 4 & $4 \%$ \\
\hline Both & 17 & $17 \%$ \\
\hline None & 8 & $8 \%$ \\
\hline Total & 100 & $100 \%$ \\
\hline
\end{tabular}




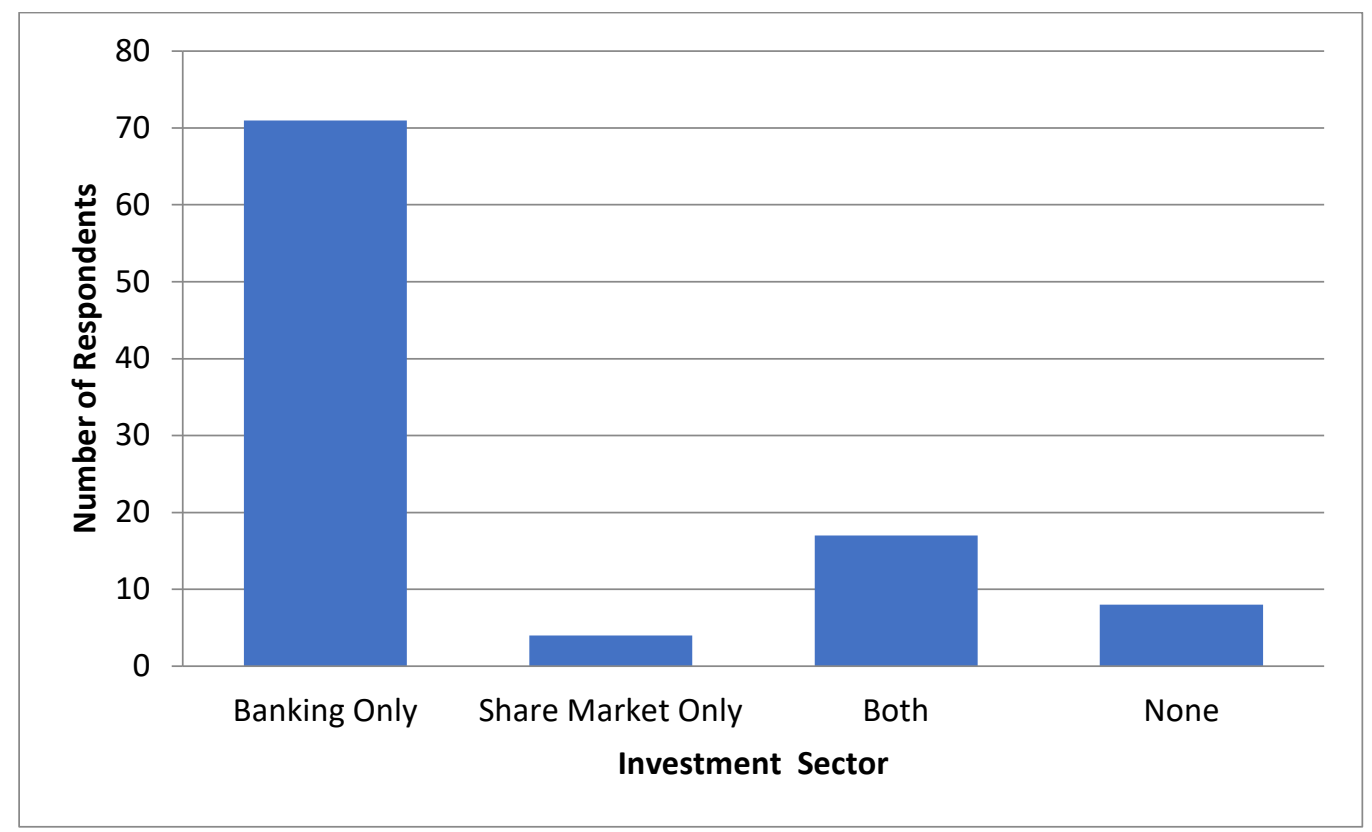

Figure 1: Investment sector of Teaching Faculties

From the above table it is found that most of the teaching faculties (71\%) invested only in Banking Sector and as per the research report it is again proved that people of India not much invested in stock market. So here only $4 \%$ of teaching faculties invested in stock market.17\% of the respondents invested both the sector and $8 \%$ of people invested neither invested in banking sector nor in Share Market avenues. They may save their earnings in home or else they spend full amount what they earned.

\subsection{PROBLEMS FACED WHILE MAKING INVESTMENT}

Everyone wants to invest in one or other investment avenues but certain factor which prevents them to investment. Therefore researcher asked the respondents what are the problems faced by respondent while they making investment. The following table and charts shows that problems faced by the respondents.

Table 3: Problems faced while making Investment

\begin{tabular}{|c|c|c|}
\hline Problems & No. of the respondents & Percentage \\
\hline Overbearing procedures and general inefficiencies of registrars & 6 & $6 \%$ \\
\hline Inadequate information about the quoted companies & 16 & $16 \%$ \\
\hline Global financial crisis and capital market crash & 10 & $10 \%$ \\
\hline Paucity of investible funds & 2 & $2 \%$ \\
\hline Low returns from investment & 40 & $40 \%$ \\
\hline Lack of transparency and inadequate supervision/regulation & 2 & $2 \%$ \\
\hline High cost of transaction & 6 & $6 \%$ \\
\hline Insincere and dishonest stockbrokers & 2 & $2 \%$ \\
\hline Lack of understanding of capital market dynamics & 8 & $8 \%$ \\
\hline Policy summersaults & 2 & $2 \%$ \\
\hline Share price manipulation & 4 & $4 \%$ \\
\hline No Problems & 2 & $2 \%$ \\
\hline Total & 100 & $100 \%$ \\
\hline
\end{tabular}




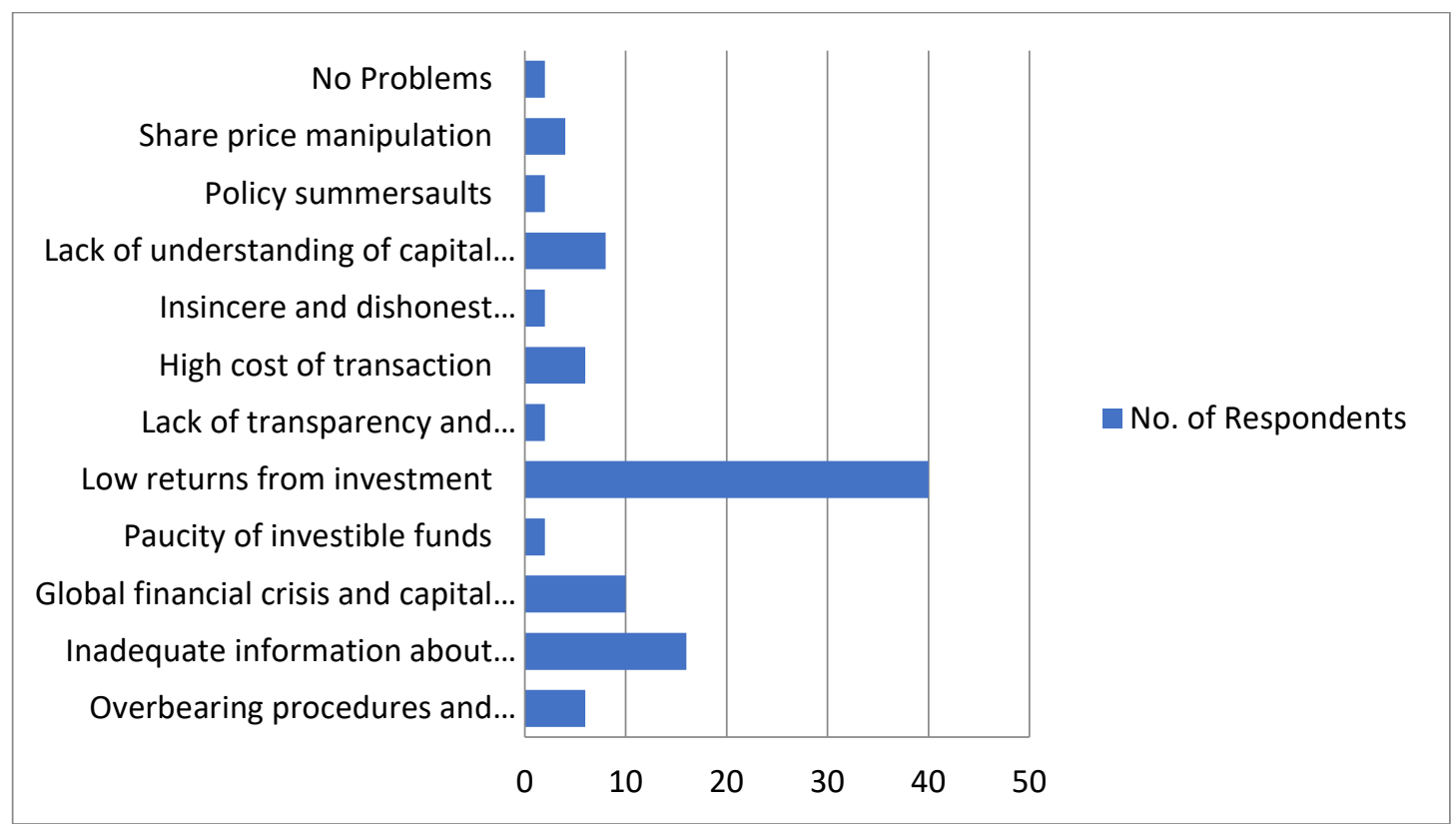

Figure 2: Problems faced by teaching faculties while making Investment

From the above table and charts clearly shows that Majority of respondents (40) faced problems of low rate of return. Here in this table it is find that most of the investors have problems like lack of information about quoted share in stock market and their price movements. In addition to these most of the respondents don't have idea about what is stock market and their operation.6\% of the people believed that cost of transaction became hurdle for investment.

\subsection{REASONS FOR NOT INVESTING IN STOCK MARKET}

From Table No.2 it is clears that majority of teachers are investing in Banking investment avenues and very less number of teachers are investing in Stock market. Therefore in order to find out the reasons for not investing in stock market researcher asked respondents about the same.

Table 4: Reasons for Not Investing in Stock Market

\begin{tabular}{|c|c|c|c|c|}
\hline Reasons & Level of Agreement & $\begin{array}{c}\text { No. of } \\
\text { respondents }\end{array}$ & $\begin{array}{l}\text { Weighted } \\
\text { mean }\end{array}$ & Rank \\
\hline \multirow[t]{5}{*}{ Fear of Risk } & Strongly Agree & 46 & \multirow[t]{5}{*}{4.13} & \multirow[t]{5}{*}{1} \\
\hline & Agree & 32 & & \\
\hline & Neutrol & 14 & & \\
\hline & Disagree & 5 & & \\
\hline & Strongly Disagree & 3 & & \\
\hline \multirow[t]{5}{*}{ Lack of Knowledge } & Strongly Agree & 35 & \multirow[t]{5}{*}{3.72} & \multirow[t]{5}{*}{2} \\
\hline & Agree & 31 & & \\
\hline & Neutrol & 11 & & \\
\hline & Disagree & 17 & & \\
\hline & Strongly Disagree & 6 & & \\
\hline \multirow{5}{*}{$\begin{array}{l}\text { Less Convenience } \\
\text { when compared to } \\
\text { Banking }\end{array}$} & Strongly Agree & 16 & \multirow[t]{5}{*}{3.67} & \multirow[t]{5}{*}{3} \\
\hline & Agree & 59 & & \\
\hline & Neutrol & 8 & & \\
\hline & Disagree & 10 & & \\
\hline & Strongly Disagree & 7 & & \\
\hline \multirow[t]{2}{*}{ Low Income(Earning) } & Strongly Agree & 17 & \multirow[t]{2}{*}{3.47} & \multirow[t]{2}{*}{4} \\
\hline & Agree & 49 & & \\
\hline
\end{tabular}


Dr. Yathish Kumar, and Mr. Abhinandan

\begin{tabular}{|c|c|c|c|c|}
\hline & Neutrol & 10 & & \\
\hline & Disagree & 12 & & \\
\hline & Strongly Disagree & 12 & & \\
\hline \multirow[t]{5}{*}{ Fear of cheating } & Strongly Agree & 24 & \multirow[t]{5}{*}{3.45} & \multirow[t]{5}{*}{5} \\
\hline & Agree & 35 & & \\
\hline & Neutrol & 14 & & \\
\hline & Disagree & 16 & & \\
\hline & Strongly Disagree & 11 & & \\
\hline \multirow{5}{*}{$\begin{array}{l}\text { Low Savings(Earning- } \\
\text { Expenses) }\end{array}$} & Strongly Agree & 20 & \multirow[t]{5}{*}{3.43} & \multirow[t]{5}{*}{6} \\
\hline & Agree & 39 & & \\
\hline & Neutrol & 16 & & \\
\hline & Disagree & 14 & & \\
\hline & Strongly Disagree & 11 & & \\
\hline \multirow{5}{*}{$\begin{array}{c}\text { No time to analyze } \\
\text { market }\end{array}$} & Strongly Agree & 28 & \multirow[t]{5}{*}{3.36} & \multirow[t]{5}{*}{7} \\
\hline & Agree & 31 & & \\
\hline & Neutrol & 13 & & \\
\hline & Disagree & 5 & & \\
\hline & Strongly Disagree & 23 & & \\
\hline \multirow{5}{*}{$\begin{array}{l}\text { Lack of Motivation/No } \\
\text { reference }\end{array}$} & Strongly Agree & 15 & \multirow[t]{5}{*}{3.31} & \multirow[t]{5}{*}{8} \\
\hline & Agree & 41 & & \\
\hline & Neutrol & 16 & & \\
\hline & Disagree & 16 & & \\
\hline & Strongly Disagree & 12 & & \\
\hline \multirow{5}{*}{$\begin{array}{l}\text { Stock Market } \\
\text { regulation }\end{array}$} & Strongly Agree & 7 & \multirow[t]{5}{*}{3.25} & \multirow[t]{5}{*}{9} \\
\hline & Agree & 44 & & \\
\hline & Neutrol & 26 & & \\
\hline & Disagree & 13 & & \\
\hline & Strongly Disagree & 10 & & \\
\hline \multirow{5}{*}{$\begin{array}{l}\text { Not interested in Stock } \\
\text { Market Investment }\end{array}$} & Strongly Agree & 16 & \multirow[t]{5}{*}{3.14} & \multirow[t]{5}{*}{10} \\
\hline & Agree & 32 & & \\
\hline & Neutrol & 16 & & \\
\hline & Disagree & 22 & & \\
\hline & Strongly Disagree & 14 & & \\
\hline \multirow{5}{*}{$\begin{array}{l}\text { Less Liquidity when } \\
\text { compared to other } \\
\text { Investment avenues }\end{array}$} & Strongly Agree & 13 & \multirow[t]{5}{*}{3.07} & \multirow[t]{5}{*}{11} \\
\hline & Agree & 40 & & \\
\hline & Neutrol & 11 & & \\
\hline & Disagree & 13 & & \\
\hline & Strongly Disagree & 23 & & \\
\hline Lack of Family & Strongly Agree & 17 & 3.06 & 12 \\
\hline Support & Agree & 24 & & \\
\hline & Neutrol & 18 & & \\
\hline & Disagree & 30 & & \\
\hline & Strongly Disagree & 11 & & \\
\hline Age Factor & Strongly Agree & 9 & 2.69 & 13 \\
\hline & Agree & 21 & & \\
\hline & Neutrol & 27 & & \\
\hline & Disagree & 16 & & \\
\hline & Strongly Disagree & 27 & & \\
\hline Does not provide good & Strongly Agree & 3 & 2.55 & 14 \\
\hline return & Agree & 25 & & \\
\hline
\end{tabular}




\begin{tabular}{|c|c|c|c|c|}
\hline & Neutrol & 26 & & \\
\hline & Disagree & 16 & & \\
\hline & Strongly Disagree & 30 & & \\
\hline \multirow[t]{5}{*}{ Less Tax benefits } & Strongly Agree & 3 & \multirow[t]{5}{*}{2.52} & \multirow[t]{5}{*}{15} \\
\hline & Agree & 20 & & \\
\hline & Neutrol & 31 & & \\
\hline & Disagree & 18 & & \\
\hline & Strongly Disagree & 28 & & \\
\hline \multirow{5}{*}{$\begin{array}{l}\text { Not interested in } \\
\text { creating wealth }\end{array}$} & Strongly Agree & 3 & \multirow[t]{5}{*}{2.33} & \multirow[t]{5}{*}{16} \\
\hline & Agree & 14 & & \\
\hline & Neutrol & 29 & & \\
\hline & Disagree & 21 & & \\
\hline & Strongly Disagree & 33 & & \\
\hline
\end{tabular}

Source: Primary Data, 2018

In order to know the main reasons for most of retail investors hesitate to invest in stock market, therefore researcher asked the respondents about the same. From their response it is found that Fear of risk, lack of knowledge and Less Convenience when compared to Banking are the main three reasons.

\section{Major Findings}

- Majority of respondents (88\%) invest Banking investment avenues and only $21 \%$ of respondents invest in Share market avenues.

- A main problem faced by investor was low return given by their investment.

- Risk involved in stock market and Lack of knowledge about stock market makes investor to withdraw from stock market.

- Low Income and low saving is considered as factor influence on investment decision.

- There is no family support to get into stock market.

- Majority of the respondents' opinion that age is not a matter to get into market.

- Majority of the respondents interested in creating wealth.

\section{Conclusion}

Why most people afraid of investing in stock market? The main reason is the people had myth of "Not many people make money in stock market" but reality is if you invest regularly for long term then anyone can make money. Many of the people are unaware towards stock investing, they do not know how much returns they can get by investing in stock market, villager doesn't know how to earn from stocks, a local retail shop owner does not know what is demat and trading account and many of them hasn't ever met an investor or trader in his entire life.

This is all because of lack of awareness; in short unawareness is one of the biggest reasons why most Indians do not invest in stocks.

The risk is always involved in stock market no matter how many studies you have done and how fundamentally strong the company is most of the conservative Indians are not willing to take a risk on their hard earned money and considers 4\% return from the savings account as safe. The risks involved in the market stops these people from investing in stocks. Therefore SEBI, Stock Broking Companies and Financial Institutions have to bring awareness about stock market in urban and semi urban areas. They have to conduct seminars on stock market to bring awareness about market.

\section{SOURCES OF FUNDING}

This research received no specific grant from any funding agency in the public, commercial, or not-for-profit sectors. 


\section{CONFLICT OF INTEREST}

The author have declared that no competing interests exist.

\section{ACKNOWLEDGMENT}

None.

\section{REFERENCES}

[1] https://www.quora.com/Why-do-people-not-invest-in-stock-market-when-we-have-seen-tremendousresults-in-long-term-investments

[2] https://www.google.com/search?rlz=1C2GCEA_enIN755\&source=hp\&ei=90SOW9fXG5Lb9Q0_zo24BQ\&q= behavioural+finance+and+investment+decisions\&oq=behavioural+finance+a\&gs_l=psyab.1.1.0110.2859.21229.0.24828.21.14.0.7.7.0.278.1678.6j2j4.12.0....0...1c.1.64.psyab..2.19.1720...0i131k1.0.accPvlpULGg

[3] https://www.google.co.in/search?q=investment+behaviour+of+teaching+faculty\&oq=investment+behaviou $\mathrm{r}+\mathrm{of}+$ teaching+faculty\&aqs=chrome...69i57.18714j0j8\&sourceid=chrome\&ie=UTF-8

[4] http://citeseerx.ist.psu.edu/viewdoc/summary?doi=10.1.1.415.6626

[5] https://www.ijmra.us/project\%20doc/IJPSS_AUGUST2012/IJMRA-PSS1560.pdf

[6] http://researchersworld.com/ijms/vol5/issue1_1/Paper_03.pdf 